\title{
DINAMIKA PELAKSANAAN IBADAH HAJI DI DESA LABBO - BANTAENG
}

\author{
M. Arsyad MG.
}

\begin{abstract}
ABSTRAK
Bagi masyarakat seperti Desa Labbo di Kabupaten Bantaeng, Sulawesi Selatan, pelaksanaan ibadah haji merupakan fokus perhatian setiap tahun, kecenderungan orang menunaikan ibadah haji terns meningkat dari tahun ke tahun. Apa sebenamya yang memotivasi antusiasme masyarakat untuk melakukan ibadah haji, dengan menggunakan metode kualitatif, khususnya wawancara mendalam ditemukan sejumlah faktor, selain motivasi ibadah (agama) hal lain yang ikut berpengaruh adalah faktor sosial ekonomi dan budaya. Kealitas seorang haji (haji mabrur) sangat ditentukan oleh tarik menarikdari sejumlah faktor tersebut.
\end{abstract}

\section{PENDAHULUAN}

\section{A. Latar Belakang dan Masalah}

Ibadah haji sebagai bagian dari sistem ajaran wahyu yang abadi dan murni yang termaktub dalam Alquran dan Hadis Rasulullah. Berbagai aspek sosial budaya yang para jamaah haji mengitari realitas historis pelaksanaan ibadah haji, pada kenyataannya tidak lagi murni dan statis, melainkan mengalami pemekaran dan dinamis. Di Desa Labbo Tompobulu Bantaeng, masalah perhajian berkaitan dengan aspek-aspek ideologi, politik, ekonomi, sosial, budaya, pertahanan dan keamanan, yang lazim disebut dengan akronim IPOLEKSOSBUDHANKAM. Dengan semakin meningkatnya jumlah jamaah haji pada setiap tahunnya, maka ibadah haji merupakan fenomene sosial keagamaan yang menarik untuk dikaji.

Di Sulawesi Selatan pada umumnya dan di Desa Labbo khususnya, minat masyarakat/ummat Islam untuk menunaikan ibadah haji setiap tahun semakin meningkat ditandai dengan semakin meningkatnya jumlah jamaah haji yang berangkat menunaikan ibadah haji setiap tahun. Fenomena ini mempunyai kaitan kausatif dengan dinamika kehidupan sosial ekonomi dan budaya masyarakat. Bahwa meningkatnya jumlah jamaah haji setiap tahun dapat mengindikasikan kemantapan iman serta pengetahuan dan penghayatan keagamaan umat semakin kuat yang ditopang dengan persepsi dan kognisi keagamaan yang relevan tentang ibadah haji. Disisi lain, meningkatnyajumlah jamaah haji setiap tahun itu mengindikasikan tingkat pendapatan masyarakat semakin memadai hingga mereka dapat menemukan kemudahan-kemudahan dalam hal memperoleh biaya atau ongkos naik haji $(\mathrm{ONH})$. Hal lain disebabkan karena semakin lancarnya prosedur pengurusan perjalanan dan pelaksanaan ibadah haji itu sendiri baik di tanah air Indonesia maupun di tanah Suci Saudi Arabia. Jadi menyangkut persepsi dan pengalaman para jamaah haji dalam kaitannya dengan struktur.

Pada konteks lain bahwa adanya kaitan dengan motivasi pelaksanaan ibadah haji dilatari posisi dan peranan sosial jamaah haji dalam Desa Labbo, baik menurut persepsi jamaah haji itu sendiri maupun pandangan masyarakat Bantaeng. Hal inipun menyangkut pengalaman jamaah haji dalam kaitan dengan struktur dan sistem pelapisan sosial yang berlaku. 
DINAMIKA PELAKSANAAN IB ADAH HAJI

DI DESA LABBO - BANTAENG

Hal-hal itulah yang diangkat sebagai permasalahan dalam penelitian ini yang secara keseluruhan menggambarkan dinamika pelaksanaan ibadah haji, ditelusuri data dan informasi yang terkait, kemudian menjelaskan melalui analisis teoritis oleh peneliti.

\section{B. Tujuan dan Kegunaan Penelitian}

Dengan mengacu kepada latar belakang dan permasalahan yang dikemukakan di atas, penelitin ini bertujuan untuk :

1. Mengetahui motif-motif yang mendorong umat Islam melaksanakan ibadah haji.

2. Mengetahui pandangan masyarakat type komunitas Makassar Bantaeng tentang haji dan orang haji.

3. Mengetahui persepsi jamaah haji itu sendiri tentang ibadah haji demikian pula menyangkut persiapan material (cara memperoleh $\mathrm{ONH}$ ) persiapan rohaniah (upacara/kegiatan spiritual lain) yang dilakukan sebelum berangkat menunaikan ibadah haji.

4. Mengetahui posisi dan peran-peran sosial seorang haji dalam komunitas Makassar Bantaeng.

5. Mengetahui persepsi jamaah haji tentang penyelenggaraan dan pelayanan ibadah haji.

Hasil penelitian ini diharapkan bermanfaat untuk :

1. Bagi instansi terkait dengan tugas dan kegiatan penyelenggaraan ibadah haji, baik secara instansional/sektoral maupun secara koordinatif dalam wadah kepanitiaan, sebagai masukan dalam rangka upaya perbaikan dan penyempurnaan.

2. Bagi kegiatan penelitian lain yang membutuhkan informasi yang relevan dengan hasil penelitian ini, atau kegiatan penelitian lanjutan dengan fokus pengamatan dan skala yang lebih luas, baik menyangkut wilayah/lokasi (misalnya meliputi kawasan timur Indonesia sehubungan dengan posisi Kota Ujungpandang, Ibukota Propinsi Sulawesi Selatan selaku pusat embarkasi dan debarkasi haji kawasan timur Indonesia) maupun menyangkut permasalahannya.

\section{PENGERTIAN KONSEP}

Sebagaimana dikemukakan bahwa pelaksanaan ibadah haji melibatkan komitmen dan pengalaman keagamaan para jemaah haji yang dimaksud dengan komitmen keagamaan disini ialah keterkaitan batiniah seseorang untuk melaksanakan apa yang diyakininya sebagai kewajiban agama. Dalam pelataran haji, komitmen keagamaan berarti kesetiaan seorang muslim kepada paham dan atau persepsinya sendiri tentang ibadah haji, dan kesediaannya melakukan tindakan-tindakan yang dilakukan dan perasaan atau keyakinan telah mengalami sendiri keadaan tertentu yang berkaitan dengan sesuatu yang super natural. Dalam hal haji, pengalaman keagamaan itu diperoleh baik sebelum berangkat ke Tanah Suci, saat berada di Tanah Suci maupun setelah kembali ke Tanah Air.

Yang dimaksud dengan sistem kognisi keagamaan ialah seperangkat gagasan keyakinan dalam hal ini mengenai haji yang dijadikan acuan oleh sekelompok orang atau suatu komunitas tertentu yang menjadi landasan bagi tumbuhnya apa yang disebut

"Komunitas Kognitif yakni gagasan dan keyakinan yang muncul menyertai keber-adaan dan suatu type komunitas etnis. Struktur yang dimaksudkan di sini meliputi, baik struktur kewenangan/kekuasaan maupun struktur sosial.

Yang pertama berkenaan dengan penentuan kebijaksanaan dan ketentuanketentuan resmi menyangkut pelaksanaan ibadah haji; sedangkan yang kedua berkenaan dengan jaringan-jaringan relasi dan hubungan sosial yang melibatkan jamaah haji sebagai 
DINAMIKA PELAKSANAAN IBADAH HAJI DI DESA LABBO - BANTAENG

salah satu komponen pelaku. Dimaksudkan dengan posisi sosial di sini ditekankan pada pelapisan sosial keagamaan dan mobilitas vertikal para haji di dalamnya.

Adapun yang dimaksud dengan dinamika pelaksanaan ibadah haji disini adalah dinamika yang timbul dalam hubungan baik asosiatif maupun kausatif antara ajaran Islam tentang haji dengan komitmen dan pengalaman yang dianggap para pelaku haji sebagai rangkaian pelaksanaan ibadah haji, termasuk hubungan yang bersifat individual dengan struktur yang mewadahinya.

\section{PANDANGAN MASYARAKAT TENTANG HAJI}

Pandangan masyarakat tentang haji digambarkan berbagai situasi dan kondisi hasil deskripsi dari orang haji yang melakukan ibadah haji pada musim haji yang variatif. Orang haji yang dimaksudkan adalah mereka yang digolongkan santri dan non santri yang melakukan ibadah haji pada musim yang sama, seperti berikut :

\section{A. Pandangan Umum Masyarakat tentang Haji}

1. Musim Haji sebeium tahun 1967

Santri HA usia 57 tahun (57) RT I dan non santri HS (61) RT I masing-masing di RK I dan RK III Dusun Ganting, mengemukakan pandangannya bahwa :

a. Berpanctangan yang sama, tentang hal-hal yang memotivasi mereka untuk melakukan ibadah haji sebagai suatu perwujudan iman bagi setiap muslim melakukan rukun atau pilar Islam yang kelima, adalah sebagai ibadah semata tanpa motivasi lain.

b. Kedua-duanya memiliki peluang dan kesempatan yang sama, yakni baru satukali menunaikan ibadah haji di tanah suci.

c. Tentang keinginan, mereka ingin melakukan ibadah haji sesuai kemampuan yang diberikan oleh Allah SWT.

d. Dalam kancah kehidupan kadangkala sulit memilih alternatif antara kepentingan duniawi dengan kepentingan naik haji, mereka memprioritaskan alternatif naik haji.

2. Musim Haji Tahun 1967-1979

Santri HU (47) RT. II dan non santri HN (58) RT. II masing-masing di RK III Dusun Ganting, menyatakan pandangannya sebagai berikut :

a. Tentang motivasi keduanya cenderung sama yakni untuk ibadah semata, namun santri HU baginya selain dari itu juga sebagai penghapus dosa dan alasannya adalah berdasar dari sebuah Hadis yang diriwayatkan oleh Ahmad dan Thabrani yang artinya : Haji mabrur pahalanya tiada lain kecuali surga: dan Quran surat Al Baqarah ayat 198 yang artinya Tiada ada dosa bagimu untuk mencari karunia (rezki hasil perniagaan) dari Tuhanmu.

b. Peluang Santri HU menunaikan ibadah haji sudah dua kali dimungkinkan pengumpulan ONHnya bersumber dari hasil panenan kopi jenis arabika, cengkeh dan jualjualan kebutuhan sehari-hari, ketimbang non Santri HN baru menunaikan ibadah haji satu kali dimungkinkan karena sebagai guru SD yang tekun menabung.

c. Tentang keinginan untuk berapa kali naik haji bagi mereka tergantung dari adanya saja kemampuan, namun santri HU dengan jumlah anggota keluarga 9 orang : isteri dan dua orang anaknya sudah diikutsertakan naik haji. Tiga orang diantaranya anaknya dikuliahkan di IAIN dan UMI masing-masing di Ujungpandang, sementara non Santri HN dengan jumlah anggota keluarga 4 
orang : belum ada yang naik haji selain dirinya sendiri, dua orang di antara anaknya dikuliahkan di UNISMUH dan IAIN masing di Ujungpa-idang.

d. Tentang alternatif mana yang diprioritaskan dalam dilematis antara naik haji dengan urusan lain. Kesamaan pandang mereka adalah memprioritaskan memenuhi kebutuhan ekonomi rumah tangga dahulu. Terbukti baik HU maupun HN sama-sama mempersiapkan SDM bagi generasinya, dengan menguliahkan anak-anaknya pada perguruan tinggi di Ujungpandang.

3. Musim Haji Tahun 1980-1985

Santri HJ (44) RT. I dan non Santri $\mathrm{HH}$ (45) RT. I masing-masing di Dusun Ganting, yang mengekspresikan pandangannya bahwa :

a. Motivasi mereka sama, yakni sebagai ibadah semata alasan mereka sesuai "Talbiyah" yang artinya : Aku datang memenuhi panggilan-Mu Ya Allah, aku datang memenuhi panggilan-Mu, aku datang memenuhi pangilan-Mu, tidak ada sekutu bagi-Mu, sesungguhnya segala puji, nikmat dan segenap kekuasaan adalah milik-Mu, tiada sekutu bagi-Mu.

b. HJ berdagang hasil bumi dan petani cengkeh membuat mereka sudah dua kali naik haji, sementara HH kenyatannya barn sekali naik haji.

c. Keinginan untuk berapa kali naik haji, mereka memiliki keinginan yang sama yakni tergantung kemampuan yang ada.

d. Dilemaiis antara kepentingan naih haji dengan urusan lain, bagi mereka sama-sama memprioritaskan kepentingan pemenuhan kebutuhan ekonomi rumah tangga, alasannya bahwa syarat haji yang kelima adalah istita'ah pengertiannya bahwa setiap orang belum memenuhi syarat tersebut belum wajib atasnya menunaikan ibadah haji.

4. Musim Haji Tahun 1986 - 1990

Santri HMh (52) RT. 2 dan non Santri HMs (30) RT. 2 masing-masing di RK. I Dusun Ganting, mengemukakan sebagai berikut :

a. Mereka memiliki motivasi yang sama, yakni sebagai ibadah semata. Keyakinan mereka dilandaskan pada sebuah Hadis Nabi yang artinya : Barang siapa datang berhaji sematamata karena Allah, diampuni segala dosanya yang telah diperbuatnya dan memberi bantuan dia pada orangorang yang didoakannya.

b. Walaupun sesungguhnya mereka berbeda latar belakang namun kenyataannya, mereka sama-sama satu kali menunaikan ibadah haji.

c. Dalam hal keinginan untuk berapa kali mau naik haji, mereka mempunyai keinginan yang sama, yakni sesuai kemampuan yang dimilikinya.

d. Faktor ekonomi sangat mempengaruhi tentang stabilitas instita'ah bagi calon jamaah haji, maka statmen $\mathrm{HMh}$ dan $\mathrm{HMs}$ tentang memenuhi kebutuhan ekonomi rumah tangga didahulukan dari kebutuhan lainnya menurut mereka itu tepat baginya.

5. Musim Haji Tahun 1991-1995.

Santri HL (60) RT. 2 dan non Santri' $\mathrm{HMu}$ (45) RT. 1 masing-masing di RK. I dan RK III Dusun Ganting, berpandangan bahwa :

a. Mereka mempunyai kesamaan pandang tentang motivasi yuriduwajhallahi taala yang diartikannya : semata-mata karena Allah, yang mempunyi dua alasan : pertama bahwa diyakininya Allah SWT mengampuni secara total 
dosa-dosa yang mereka (yang naik haji sebagai ibadah semata) telah perbuat; dan kedua bahwa diyakininya Allah SWT memberi bantuan atau dispensasi pada mereka (yang naik haji karena Allah) termasuk orang-orang yang didoakannya.

b. Seiring kemampuan dan realita mereka sama-sama baru sekali menunaikan ibadah haji. Dibalik itu mereka beralasan bahwa menunaikan ibadah haji diwajibkan hanya sekali seumur hidup, selanjutnya yang kedua kalinya dan untuk seterusnya hukumnya yang dipahaminya hanya sunnat.

c. Tentang keinginan untuk berapa kali naik haji, mereka punya statemen yang sama yakni sesuai kemampuan. Statemen tersebut dilandasi oleh pemilikan standar ekonomi yang sama menggantungkan harapan pada hasil panen kebun kopi (arabika) nya.

d. Santri HL memprioritaskan kebutuhan ekonomi rumah tangga, dengan pertimbangan mereka atas pengertian istita'ah. Dipahaminya istita'ah (usia dan ekonomi rumah tangga) sangat sensitif baginya. Lain halnya dengan non Santri HMu tentang istita'ah dipahaminya ketika dalam kondisi cukup ONH dan sehat bersegeralah menunaikan ibadah (Rukun) haji, makanya mereka lebih mendahulukan menunaikan ibadah haji ketimbang kepentingan urusan lain.

\section{B. Persepsi Jamaah Haji Tentang Haji}

Persepsi merupakan proses pengamatan seseorang yang berasal dari komponen kognisi. Persepsi ini dipengaruhi oleh faktor-faktor pengalaman, proses belajar, cakrawala dan pengetahuannya (Prof. Dr. Mar'at, 22 : 1981). Persepsi jamaah tergambar dalam pendapat, tanggapan dan, pengalaman mereka sebagai berikut.

\section{Pendapat}

Kebanyakan dari golongan Santri, yang menunaikan ibadah haji pada musim haji yang berbeda-beda, mengatakan terus terang bahwa timbulnya niat kami untuk naik haji pada wkatu sebelum rampungnya Ongkos Naik Haji (ONH). Niat mereka diperkuat oleh keyakinannya bahwa, pentingnya niat didahulukan daripada terkumpulnya $\mathrm{ONH}$ secara utuh atas pertimbangan, bahwa siapa tahu di dalam proses pengumpulan ONH Allah SWT memanggil (meninggal dunia) menghadap, maka Inysa Allah akan memperhitungkan niat kami.

Teori Mar'at tentang persepsi masih relevan dengan statemen mereka (Santri dan non Santri), bahwa haji sebagai suatu obyek psikologik yang adanya di tanah suci - di tanah haram di Arafah yang selain sakral bagi umat Islam, juga merupakan sesuatu yang baru (bagi jamaah haji yang baru satu kali naik haji).

\section{Tanggapan}

Tanggapan jamaah haji di lokasi penelitian erat kaitannya dengan teori di atas utamanya dalam hal kognisi, bahwa faktor proses belajar atau sosialisasi memberikan bentuk dan struktur terhadap apa yang dilihat. Sedangkan pengetahuannya dan cakrawalanya memberikan arti terhadap obyek psikologik tersebut (23: 1981).

Kebanyakan dari golongan Santri, memberi tanggapanna bahwa sebenarnya kami mulai belajar manasik haji sejak dibangku sekolah. Ada pula belajar dari Ulama dan Muballig. Ulama yang tersohor di lokasi penelitian adalah K.H. Abdul Hamid (70) di Banyorang, adapun yang dari luar 
DINAMDCA PELAKSANAAN IBADAH HAJI

DI DESA LABBO - BANTAENG mereka itu adalah K.H. Mustafa Adam yang Iebij dikenal dengan sapaan Syekh Puang Arafah dan, Syekh Abdul Azis kedua-duanya berasal dari daerah tetangga (Kabupaten Bulukumba); sementara daerah (tetangga lainnya (Kabupaten Jeneponto) adalah K.H. Pabe. Melalui Ulama yang ternama di atas, mereka (Santri dan Non Santri) berusaha mencari keseimbangan dalam bidang kognisinya sampai terbentuknya sikap yang diharapkan dari masingmasing yang bersangkutan. Apabila terjadi ketidak keseimbangan individu akan berusaha mengubahnya sehingga terjadi keseimbangan kembali.

Hasil input dari tempat berguru/belajar sebagaimana tersebut di atas di seimbangkan dengan perolehan (kondisi akhir) ekonomi, maka kebanyakan (Santri dan non Santri) cenderung melaksanakan haji ifrad; namun secara eksplisit mereka menyatakan dengan dorongan keyakinan bahwa, sepala-pala kita melaksanakan haji ini, harus dengan kesiapan yang mantap baik fisik maupun mental, karena naik haji yang pertama ini yang menjadi kewajiban, adapun untuk berikutnya itu sangat berkaitan erat dengan kemampuan dan rezki dari Allah SWT. Dasar pertimbangan lain bahwa, keuntungan memilih cara ifrad tidak diwajibkan membayar dam (ekonomis).

3. Pengalaman

Yang diungkap disini adalah pengalaman kebanyakan dari mereka selama menunaikan ibadah haji di Tanah Suci. Secara global ketika jamaah (Santri dan non Santri Labbo) di kota Madinah dan sekitarnya - di Makkah dan sekitanya - di Arafah dan Mina.

Ketika mulai mereka berniat dan memakai pakaian ihram dari miqat, perasaan seluruh tubuh bergetar, seakan-akan disaat itu tengah menguji diri (seperti) jadi orang mati, hubungan diri sebagai hamba dengan Tuhan Yang Maha Segala-galanya tidak terputus.
Hasilnya mereka lebih waspada dalam melaksanakan rukun dan wajib haji sesuai tuntunan manasik haji.

a. Di Kota Madinah dan sekitarnya.

Perasaan khusus yang mereka alami, ketika pertama kali masuk kota Madinah, rasa bangga (sebagai ummat Muhammad) bersua dengan kota tempat Rasulullah Muhammad SAW beserta syuhada lainnya dahulu berjuang untuk kepentingan ajaran/syariat Islam.

Kebanyakan dari mereka menyatakan selalu/sering melaksanakan Sholat Arba'in berjamaah, Sholat tahiyyatul masjid dan Sholat rawatib, di Masjid Nabawi. Aktivitas tersebut diakuinya karena percaya kepada sabda Nabi SAW yang artinya : Shalat di masjidku ini (Masjid Nabawi) lebih utama 1.000 kali dibanding shalat di masjid lainnya kecuali di Masjidil Haram dan shalat di Masjidil Haram lebih utama 100.000 kali shalat dari pada masjid lainnya (Hadis ini diriwiyatkan oleh Ahmad Ibnu Huzaimah dan Hakim dalam D.V.2 : 73 - 74).

Pernyataan selalu/sering dari kebanyakan jamaah haji di lokasi penelitian, melakukan Shalat sunnah di Raodah. Karena diyakininya bahwa keutamaan Raodah adalah tempat yang makbul untuk berdoa, landasannya adalah sesuai sabda Rasulullah SAW yang artinya : ' Antara rumahku dengan mimbarku adalah Raodah (taman) di antara taman-taman Surga (Diriwiyatkan lima orang hali hadits dalam D.V.A.2: 88). Di tempat inilah mereka bermunajat tentang berbagai hajat yang dipastikannya Insya Allah mendapat berkah.

Tentang Ziarah di Makam Rasulullah (Muqshurah) dan saha- 
batnya. Di dalam Maqshurah ini terdapat selain Makam Rasulullah SAW juga makam Abubakar As Siddiq dan Umar Ibnul Khattab ra. Hampir semua responden yang mendukung penelitian ini menyatakan bahwa, ada pengalaman khusus yang dialaminya ketika berziarah di Makam Rasullullah SAW. Kehususan tersebut berupa ungkapanungkapan perasaan haru dan takjub. Keunikan lain yang dialaminya di tempat ini ketika usai shalat berjamaah bersalaman (jabat tangan) dulu, kemudian baru berdoa; kalau kebiasaan mereka dinegerinya (Bantaeng) seusai shalat berjamaah berdoa dulu kemudian baru bersalam-salaman. Di tempat ini kebanyakan jamaah menyatakan selalu dan keseringan berziarah. Demikian pula halnya di makam Baqi. Maqam Baqi adalah tanah pekuburan penduduk Madinah (sejak zaman jahiliah sampai sekarang), didalamnya selain terdapat kuburan keluarga Rasulullah SAW juga termasuk kuburan jamaah Indonesia yang meninggal dunia pada banyak musim haji yang silam (termasuk yang punya hubungan keluarga dekat dengan jamaah dari lokasi penelitian ini), sehingga dari jamaah Bantaeng menyempatkan diri berziarah ke pekuburan tersebut.

Ziarah di Masjid Quba, sering dan selalu kebanyakan dari jamaah menyatakan demikian. Letak Masjid Quba jauh dari poros jalan Madinah - Mekkah - Jeddah, didirikan (pertama) oleh Rasulullah SAW (209-622 M) di atas tanah milik Kalsum bin Hadan asal kabilah Amir bin Auf. Keinginan mereka ziarah atas keyakin\&n dari sebuah hadis Rasulullah SAW yang menganjurkan datang ke Masjid Quba yang artinya : Siapa saja yang bersuci (membersihkan diri dari najis dan hadas) di rumahnya, kemudian datang ke Masjid Quba dan shalat di dalamnya, maka dia mendapatkan pahala seperti pahala umrah (Hadis riwayat Ahmad Nasa'i Ibnu Majah, Hakim dan dia berkata sanadnya sahih dalam D.V.A.2 : 92093. Untuk merebut pahala umrah bekal akherat, dengan senang menyempatkan diri berkunjung ke Masjid Quba.

Ziarah di Jabal Uhud (nama sebuah bukit besar di Madinah dan ditempat inilah terjadinya peristiwa Perang Uhud pada zaman Rasulullah SAW). Jabal Uhud merupakan jalur trasportasi jamaah haji, dengan posisi jalur arah kota Mekkah - Madinah - Kota Jeddah, dengan pertimbangan pengembangan arus lalulitas kendaraan semakin padat, maka kebijakan pemerintah setempat sejak tahun 1984 dilakukan pengalihan atau perubahan jalur.

Ziarah di Masjid Qiblatain (kiblat dua), pertamanya masjid ini bernama Masjid Bani Salamah, pada awalnya Rasulullah SAW di tempat ini shalat menghadap (Kiblat) ke arah Baitul Makdis (Masjid Aqsa),perubahan arah kiblat menjadi kearah Masjid Haram atas dasar wahyu Allah SWT (meialui Al Bakarah ayat 144) kepada Rasulullah SAW tatkala beliau Sholat Zuhur tepatnya pada hari Senin bulan Rajab tahun ke 2 Hijriyah (D.R.A.2 : 98). Dari kebanyakan jamaah menyatakan sering/selalu ziarah ke Masjid Qiblatain.

Ziarah di di Khadat atau di Masjid Khamzah, sedikit dari jamaah yang menyatakan sering/selalu ziarah ke tempat tersebut. Kata Khandak berarti parit (penggalian parit) benteng pertahanan perang antara Kafir Quraisy beserta seku- 
tunya dari Yahudi dengan Rasulullah SAW beserta jajarannya (Syawal tahun kelirna Hijriyah). Dulunya bukit peninggalan perang tersebut ada 5 buah bekas pos penjagaan, kini tinggal dijumpai dengan (nama) Masjid Sab'ah atau Masjid Khamzah.

Pengalaman khusus yang dialami (selama \pm 9 hari) di Madinah setelah wukuf, usai menyelesaikan shalat arbain, yang menjadi perhatian jamaah adalah tentang karakter orang Madinah nampaknya lebih ramah ketimbang orang Mekkah; dan ketika mencari teman (yang hilang) dengan rasa solider secara bersama-sama anggota seregu mencari dengan cara mengelilingi (untuk pertama kalinya) Masjid Nabawi sambil bertasbih dan bersalawat, tak selang lama teman yang hilang dapat ditemukan kembali.

Kontak dengan jamaah haji asing selama di Madinah, interaksi yang terjadi antara jamaah asal Bantaeng dengan jamaah asal Malaysia. Kontak ini dalam kepentingan sebatas antara produsen dengan konsumen (cendra mata), itupun dimungkinkan adanya kepadanan alat komunikasi antara bahasa Indonesia dan bahasa Melayu.

b. Di Mekkah dan Sekitarnya

Hampir semua jamaah yang mendukung penelitian ini menyatakan, ada perasaan khusus ketika pertama kali memasuki Kota Mekkah. Kekaguman bagaikan mimpi karena baru dalam hidup ini melihat dan menyaksikan langsung dengan mata kepala sendiri kota suci bagi umat Islam, tempat bertemunya berbagai ragam bangsa dan budaya dalam jumlah tak terbilang banyaknya, dengan satu tujuan suci, yakni memenuhi panggilan Baitullah untuk menunaikan Rukun Islam yang kelirna. Masalah akomodasi dilakukan antar jemput secara besar-besaran dari dan ke tempat pemondokan yang telah disediakan oleh Maktab.
Dengan kekaguman tersebut membuat mereka lelbih rutinutas bertasbih memuji Keagungan Allah SWT yang menciptakan Alam semesta, bersalawat memuji junjungan Nabi Besar Muhammad SAW pembawa rahamtan lil alamin. Hasil dari itu mereka merasakan hasiatnya sehat walafiat melaksanakan dengan baik semua rukun dan wajib haji serta semua rangkaian kegiatan ibadah haji (tuntunan manasik) walaupun cuaca sangat berdampak tetapi perasaan tetap lega.

Perasaan ketika pertama kali melihat Ka'bah (Baitullah). Semua jamaah mengungkapkan perasaannya, bahwa ketika kami pertama kali melihat Baitullah, seperti dalam posisi antara ketakutan dan tidak, kagum, terharu, dengan merendah diri bersyukur kehadirat Allah SWT, bahwa Alhamdulillah kini hamba-Mu telah datang memenuhi panggilan$\mathrm{Mu}$ Ya Allah, dan kami siap melaksanakan tawaf qudum sebagai ucapan selamat bertemu Ka'bah.

Perasaan ketika pertama kali shalat fardhu di Masjidil Haram Makkah. Semua jamaah menyatakan perasaannya, bahwa ketika kami pertama kali shalat fardhu rasa takut bertaut gembira, karena dengan kekuasaan Allah SWT kami (pada waktu itu) bisa melakukan sholat fardu di masjid yang di dalamnya terdapat Baitullah. Seolah-olah kami sholat di depan Allah SWT, dampaknya atau hasilnya kami rasakan dalam diri kami ada kedamaian dan ketenangan jiwa.

Perasaan ketika selesai melakukan Tawaf, Sa'i dan Tahallul. Semua jamaah mengungkapkan perasaannya, dikatakannya bahwa ketika rangkaian kegiatan ibadah (Tawaf, Sa'i dan Tahallul) dapat diselesaikan secara tertib dan baik. Perasaan halus yang mengatakan (dengan keyakinan) bahwa ibadah kami ini diterima oleh Allah SWT, akhirnya kami dapat berbusana haji. Dengan 
terkenakannya atribut haji tersebut pada diri kami, seketika itu pula air mata menetes kerena rasa haru dan syukur kehadirat Allah SWT.

Manfaat langsung yang dirasakan setelah minum air zamzam. Semua jamaah menyatakan adanya manfaat langsung yang dirasakan setelah minum air zam-zam. Karena diyakini berkah doa yang diajarkan nabi yang artinya: Ya Allah aku mohon pada-Mu ilmu pengetahuan yang bermanfaat, rizqi yang luas dan kesembuhan dari segala sakit dan penyakit dengan rahmat Allah $\mathrm{Mu}$ Ya Allah Tuhan Yang Maha Pengasih dari Segenap yang pengasih (D.V.A.4 : 64). Selain kandungan mineral dan rasa imani dari jamaah maka muncullah berbagai rasa, seperti perasaan segar, nyaman, sejuk, dingin (walaupun cuaca matahari panas), meyengatkan.

Frekwensi ibadah dan kegiatan Tawaf Sunnah secara khusus. Hampir semua jamaah mengatakan bahwa kami sering bahkan setiap masuk masjidil Haram Mekkah, melaksanakan Tawaf Sunnah (bukan rangkaian umrah), dengan alasan mumpun ada kesempatan berbuat kebajikan Ctawaf) yang diberikan oleh Allah SWT.

Frekwensi Ibadah dalam kegiatan mencium Hajarulatwad. Kebanyakan dari jamaah menyatakan bahwa dirinya mencium Hajarulaswad setiap selesai Tawaf sebanyak tiga kali keatas. Karena perhitungan antara keinginan (yang imani) dengan kecepatan arus manusia (yang bergerombol), demi keselamatan untuk kebajikan (rangkaian ibadah haji) lainnya.

Frekwensi ibadah dan kegiatan Umrah Sunnah. Kebanyakan jamaah yang mengatakan sempat tujuh kali ke atas melaksanakan ibadah Umrah Sunnah.

Frekwensi ibadah dan kegiatan berdoa di muka Multazam. Hampir semua jamah mengatakan bahwa setiap selesai tawaf kami berkesempatan berdoa di muka Multazam. Macam-macam doa yang kami mohonkan kehadirat Allah SWT dengan satu keyakinan Insya Allah Tuhan memperkenankan-Nya, Amin.

Frekuensi ibadah dan kegiatan Shalat Sunnah di Hijir Ismail. Hampir semua jamaah yang menyatakan setiap selesai Tawaf sering melaksanakan ibadah dan kegiatan shalat Sunnah mutlak di Hijir Ismail, berdoa sesuai tentunan yang artinya Ya Allah, Engkaulah Pemeliharaku, tiada Tuhan Selain Engkau yang menciptakan aku. Aku ini hamba $\mathrm{Mu}$, memnuhi janji dan ikatan pada$\mathrm{Mu}$ sejauh kemampuanku. Aku berlindung pada-Mu dari kejahatan yang telah kuperbuat, aku akui segala nikmat dari-Mu kepadaku dan aku akui dosaku, maka ampunilah aku. Sesungguhnya tidak ada yang dapat mengampuni doa selain Engkau sendiri. Ya Allah, aku mohon kepada-Mu, kebaikan yang oleh hamba-hamba-Mu yang saleh. Dan aku berlindung pada-Mu dari kejahatan yang hamba-hamba-Mu yang saleh meminta perlindungan pula dari padanya (D.V.A4 : 66 67). Dengan keyakinan bahwa akan membentuk sikap dan perilaku yang ideal dalam bermasyarakat dan berbangsa.

Frekuensi ibadah dan kegiatan shalat Sunnah di dekat makam Ibrahim. Hampir semua jamaah menyatakan bahwa setiap selesai Tawaf mereka laksanakan Shalat Sunnah di dekat makam Ibrahim, denga harapan kiranya Allah SWT memberi pahala seperti kelebihan-kelebihan seperti yang dipunyai oleh Nabi Ibrahim as, sembari mengagumi betapa hebat hasil karyanya dan betapa besar pengabdian dan ketabahan yang dimilikinya.

Tentang Dam (denda). Ada diantaranya yang mengatakan bahwa yang mereka lihat, ketika ada jamaah 
DINAMKA PELAKSANAAN IBADAH HAJI

DI DESA LABBO - BANTAENG

haji yang harus membayar Dam, maka kebanyakan mereka menyetor kepada Petugas Haji (TPHI) di Tanah Suci.

Cara mengatasi kesulitan di Makkah, kebanyakan jamaah mengatakan bahwa, ketika kami mengalami kesulitan di Makkah, kami meninta bantuan kepada anggota jamaah haji serongbongan. Karena jenis kesulitan yang mereka alami bisa diatasi oleh sesama jamaah tanpamelibatkan petugas haji.

Pengalaman khusus selama di Mekkah. kebanyakan jamaah mengatakan tehwa, pada saat musim haji yang kami alami keadaan cuaca sangat panas, karena keinginan untuk sentiasa sholat berjamaah di Masjidil Haram, guna selalu mendekatkan diri kepada Allah SWT, kenyataannya cuaca tersebut tidak sampai mempengaruhi kondisi fisik/kesehatan kami. Tidak terduga suatu saat dalam cuaca terik ada teman tersesat, dengan sepontanitas rasa solider kami secara bersamasama menolong untuk menemukannya, dan Alhamdulillah dapat ditemukan dengan selamat. Kasus lain, ada diantara kami (kata mereka) yang mengalami sampai dua kali masuk kota Mekkah, karena ada kesulitan tekhnis kendaraan (Pemberangkatan Ke Madinah dan gangguan tekhnis).

Maksud membeli barang khusus di Mekkah. Hampir semua jamaah mengaku membeli barang khusus di Mekkah dan masingmasing punya maksud. Ada sempat membeli berupa : kitab-kitab agama (Islam), batu permata, sajadah, jubah, sorban, tasbih, siwak, buah kurma, alat-alat permainan anakanak. Tujuan dan maksud mereka membeli selain untuk kebutuhan sendiri, juga untuk cendera mata bagi keluarga dan handai taulan di negeri dan kampun halaman.

c. Di Arafah dan Mina

Ibadah yang dialami dalam perjalanan dari Mekkah ke Arafah, waktu wukuf di Arafah, dan dalam perjalan dari arafah ke Musdalifah Mina. Kebanyakan jamaah yang mendukung penelitian ini menyatakan bahwa, ada ibadah khusus yang kami lakukan seperti: Kasus pertama, ketika menuju terowongan Mina tak terduga kehilangan arah, maka kami duduk tafakkur berdoa secara khusyu, secara kebetulan pada saat itu ada mahasiswa Kairo menuntun kearah yang kami inginkan; Kasus ke dua, ketika kesulitan mobil, sesudah dhuhur untuk meninggalkan arafah, cara mengatasinya kami kembali berdoa secara khusyu untuk pemenuhan kepentingan tersebut, masya Allah taklama kemudian diluar perhitungan fasilitas kendaraanpun dapat teratasi, Alhamdulillah.

Ibadah dan kegiatan shalat jama' taqdim Zhuhur - Ashar dilakukan waktu wukuf di Arafah. Semua jamaah menyatakan ya kami melaksanakan shalat bersama Jama' Taqdim atas Zhuhur dan Ashar waktu wukuf di Arafah.

Ibadah dan kegiatan membaca Zikir dan Doa sesuai yang ada dalam buku Manasik Haji dilakukan waktu Wukuf di Arafah. Hampir semua jamaah mengatakan, bahwa Ya, kami membaca zikir dan doa sesuai yang ada dalam buku manasik haji dilakukan waktu wukuf di arafah.

Ibadah dan kegiatan shalat bersama Jama' Taqdim Magrib Isya dilakukan waktu wukuf di Arafah. Semua jamaah mengatakan Ya, kami melaksanakan shalat bersama Jama' Taqdim atas Magrib dan Isya waktu wukuf di Arafah.

Pengalaman khusus waktu mampir di Musdalifah mengambil batu-batuan. Kebanyakan jamaah mengatakan ada pengalaman khusus. Pada saat kami tiba di Musdalifah tepat waktu malam, keadaannya gelap banyak orang pada berdesakdesakan untuk mencari batu-batuan 
(kerikil), ironisnya ada diantara kami bukan lagi batu kerikil yang diperoleh, akan tetapi tinja hewan. Akibat tidak te-tampungnya jamaah yang datang dari berbagai jurusan, maka diantara kami ada yang memilih tidur-tiduran di pasir, namun kesannya terasa masih ingin tinggal bermalam walau suasananya demikian.

Pengalaman khusus ketika Melempar Jumrah. Kebanyakan jamaah menyatakan ada pengalaman khusus. Di tempat melempar Jumrah manusia pada berdesak-desakan. Pada awalnya sulit untuk mencapai sasaran lemparan dengan tepat. Pada lontaran ke tiga, ada diantara kami terpaksa tergeser dari posisinya dikarenakan tekanan arus gerombol manusia, berselang lama dengan ketabahan hati baru kembali keposisi semula. Ada juga diantara kami karena faktor fisik yang kurang mampu menatang arus, akhirnya terhambat melontarkan Jumrah. namun dengan bimbingan Allah SWT semuanya terselesaikan.

Cara mengatasi kesulitan di Arafah dan Mina. Kesulitan yang ada berupa: kurangnya persediaan Air, kurangnya pengenalan medan sampai mudah tersesat, sengatan matahari dan, gangguan angin kencang, serta populasi sarana WC kurang, Sesungguhnya kurang dari jamaah di Lokasi penelitian yang menyatakan ada kesulitan yang dialami, namun cara yang mereka lakukan daiam mengantisipasi kelulitan tersebut di atas secara individu dengan memperhatikan sekian yang ada, nyatanya biasa.

\section{Pandangan Orang Haji Tentang Pen- gurusan dan Pelayanan}

Keadaan pelayanan petugas haji di Madinah. Kebanyakan jamaah menyatakan, bahwa keadaan pelayanan petugas haji ketika kami di Madinah baik. Wujud pandangan baik tersebut, mereka dapatkan dalam hal pelayanan tehnis ibadah haji, akomodasi, konsumsi dan, terutama penyediaan air.

Keadaam pelayanan petugas haji di Mekkah. Kebanyakan jamaah yang menyatakan, bahwa keadaan pelayanan petugas haji di Mekkah baik Kenyataan baik yang mereka maksud dalam wujud servis, pemondokan dan air bersih.

Tentang Kolektor Haji, Keloter haji yang dikenal di lokasi penelitian, berasal dari daerah tetangga seperti Bulukumba dan Jeneponto, sedang yang ada di Bantaeng sendiri dari Tompobulu. Fungsi kolektor yang ada, memperlancar urusan jamaah (jasa). Hubungan dalam kenyataan antar keluarga dan pertemanan, sasarannya bagi calon haji yang kurang mampu mengurusi kepentingannya sendiri.

\section{Peranan Orang Haji di Lingkungan Masyarakat Bantaeng di Bidang Ekonomi}

Keadaan Ekonomi antara golongan santri dan golongan non santri relatif tidak jauh beda. Kebanyakan golongan santri bergerak dibidang perkebunan (Kopi dan Cengkeh) yang selanjutnya dalam posisi selaku produsen, sementara dari golongan non santri kebanyakan bergerak dibidang jasa (pegawai negeri), leverensir dan makelar broker dari komoditi yang dihasilkan oleh para santri dengan golongan non santri dalam wujud antara produsen dengan maketing dan konsumen. Perekat lain dari hubungan bisnis (komoditi andalan daerah) tersebut di atas, karena adanya kesamaan pandang tentang aqidah yang diyakininya, adanya kesamaan pola budaya yang dilestarikan yang dikenal di lokasi dengan sebutan Sipakatau arti bebas adalah memanusi'akan manusia.

Dalam hal inkam rumah tangga. Kebanyakan jamaah mendukung penelitian ini menyatakan, bahwa ada peningkatan pendapatan rumah tangga kami setelah naik haji ketimbang sebelumnya. Faktor yang memungkinkan peningkatan inkam tersebut, seperti: pertama, dengan keyakinan doa selama di Tanah Suci diterima, hasilnya (seiring) motivasi sejalan dengan pengelolaan (perkebunan) mengikuti 
petunjuk teknis penyuluhan dinas perkebunan setempat, membuat kualitas kopi dan cengkeh meningkat; kedua, seiring dengan adanya peningkatan harga jual komoditi andalan daerah; yang ketiga, dengan status (haji) yang disandang dengan resiko (besar $\mathrm{ONH}$ ) yang telah dikeluarkan, serta memelihara kredibilitas predikat haji hams dijunjung tinggi.

Tentang adanya berkah. Semua jamaah menyatakan bahwa perasaan kami terasa berkaanya dalam hal menerima rezki setelah naik haji. Perasaan adanya berkah ketika menerima rezki itu ada, karena dimunculkan oleh beberapa faktor. Faktor petama dibuktikan adanya kesadaran tentang maknaa rezki; faktor kedua dibuktikan adanya kesadaran tentang pendayagunaan rezki dan, faktor ketiga dibuktikan adanya keyakinan tentang keberadaan rezki itu, harus ditopang dengan adanya keseimbangan antara usaha manusia dan perkenanan dari Yang Maha Kuasa (Allah SWT).

Tentang penggantian mata pencaharian setalah haji. Dari golongan santri kebanyakan mengatakan, bahwa ada pengantian dan peningkatan pendapatan setelah haji. Hal ini terjadi karena didukung oleh tiga faktor. Faktor petama karena (status) mereka adalah petani kebun dan pedagang, berarti mereka bekerja secara musiman, dalam arti mereka dituntut mewanti-wanti sikon pada musim (tanah dan panen) yang akan datang. faktor kedua karena dengan gambaran musim yang akan datang, maka mereka harus lebih sensitif dalam penyeleksi bibit, pupuk dan racun, serta kondisi lahan persamaian (kebun kopi dan cengkeh) dan; faktor ketiga adanya kemampuan persaingan bisnis, dengan tetap memposisikan doa sebagai faktor yang tidak kurang pentingnya dalam penentuan keberhasilan suatu usaha.

Kedudukan dan peranan orang haji di Desa Labbo Bantaeng di lihat dari sisisisi sosial kemasyarakatan. Di lokasi penelitian (Labbo) ini penduduk dan peranan yang menonjol adalah: orang haji, orang berilmu pengetahuan dan, orang kaya/ningrat. Diantara tiga kategori tersebut, yang paling menonjol adalah orang haji mengapa, kerena kenyataan umumnya orang haji itu adalah berlatarbelakang dari orang yang baikbaik yang memiliki ilmu pengetahuan (manasik haji) dan berduit (ONH).

Penghargaan masyarakat terhadap orang haji dalam upacara adat dan upacara keagamaan. Kebanyakan jamaah yang menyatakan, bahwa tersedia tempat khusus bagi orang haji dalam upacara tersebut di atas. Dibalik itu peneliti menemui di lokasi penelitian tentang adanya pola budaya (baik antar golongan santri maupun golongan non santri) yang namanya haji tetap eksis dalam pelbagai pelataran upacara.

Sikap masyarakat terhadap orang haji dalam tugas-tugas keagamaan . Kebanyakan dari jamaah menyatakan bahwa masyarakat menaruh kepercayaan dan pengharapan terhadap orang haji dalam tugas-tugas keagamaan. Kepercayaan dan pengharapan itu timbul karena suatu penyebab. Salah satu peyebab yang mendasar, karena status haji itu menjadi dambaan kebanyakan/lapisan masyarakat di lokasi penelitian. Penyebab lain dikarenakan adanya persepsi dikalangan pelapisan masyarakat bahwa, orang haji itu dipandang orang yang sempurna pengetahuan agamanya. Pertimbangan 
lain bahwa dengan telah dilaksanakannya rukun (Islam) yang kelima (naik haji) itu berarti telah sempurnalah keislaman orang itu.

Tentang predikat haji sekarang dapat menjadi jaminan dalam usaha. Dalam konteks predikat haji bisa-tidaknya dijadikan suatu jaminan moral dalam dunia usaha. Dari golongan santri meyatakan bahwa secara umum dapat menjadi jaminan, sementara dari golongan non santri menyatakan bahwa tergantung pada pienilaian masyarakat terhadappribadi ora:tig haji bersangkutan. Ternyata sek£ irang, predikat haji dalam dunia usaha bisa $\mathbf{i}$ diposiskan dengan etika bisnis.

Organisasi/perkumpulan orang haji di lokasi penelitian. Hampir semua jamaah yang membantu kegiatan penelitian ini menyatakan bahwa, kami mempunyai wadah pemersatu dikalangan orang haji di Desa Labbo Bantaeng ini, yang dikenal dengan nama Ikatan Persaudaraan Haji Indonesia, induknya di ibukota Daerah Tingkat II Bantaeng, Pengurusnyapun didominasi oleh tokohtokoh masyarakt yang berdomisili di ibukota, kami di Labbo sebagai anggota. Wadah tersebut berperan sebagai alat komunikasi (mediator) antara kalangan orang haji dengan kalangan pemerintah daerah (dar desa sampai kabupaten bantaeng).

\section{PENUTUP}

\section{Kesimpulan}

Haji menurut pandangan umum di lokasi penelitian, adalah suatu status terpandang bagi masyarakat pada umumnya dan bagi kaum muslim pada khususnya.
Harta benda dan kekayaan yang membuat orang muslim bisa menunaikan ibadah haji, itulah dipandang paling bermanfaat; siapa saja yang mampu melakukan hal seperti di atas maka dialah terpandang mulia di masyarakat lingkungannya.

Pendapat jamaah haji tentang haji bahwa sebelum seseorang akan menunaikan haji di tanah suci, harus lebih dahulu haji di tahah air. Dimaksud ialah: pertama, seorang calon haji (calhaj) sudah mampu mengimplementasikan empat rukun Islam (syahadatshalat-zakat-puasa) dengan baik; kedua, seorang calhaj terlebih dahulu faham menguasai terori-praktek tentang rangkaian kegiatan haji (manasik haji) di negeri sendiri. Setelah itu bam beranjak melaksanakan ibadah haji di Makkatul Mukarramah.

Tanggapan jamaah haji tentang haji, bahwa seorang dapat diakatakan sebagai seorang hamba yang patuh kepada Allah SWT, ketika orang tersebut mempu mendirikan dan menegakkan shalat (termasuk amar ma'ruf dan nahi mungkar), dan nanti sempurna pengakuannya sebagai umat Muhammad SAW, ketika ia sudah melaksanakan serangkaian kegiatan ibadah haji (manasik haji).

Pengalaman jamaah haji tentang haji, ketika mereka melaksanakan rangkaian ibadah dibeberapa tempat (suci) tertentu, berziarah dan berdoa ditempat-tempat bersejarah, mereka merasakan adanya getaran iman dan sentuhan kasih-sayang baik diyakini datangnya dari Allah SWT maupun dari Rasulullah SAW pada saat-saat tertentu, seakan-akan berhadapan langsung denganNya, sampai mereka lebih beriman dan lebih bertaqwa dari sebelumnya.

Pandangan orang haji tentang pengurusan danpelayananpetugas haji, baik 
di Mekkah, di Madinah, di Mina, maupun di Tanah Air (saat pemberangkatan dan saat pemulangan ke daerah asal) pada umumnya baik, termasuk soal teknis peribadataii maupun pemenuhan kebutuhan akomodasi dan konsumsi.

Dibidang ekonomi. Peranan orang haji dikalangan masyarakat, cukup memberi corak (mewarnai), utamanya dalam konteks transaksi perdagangan (komoditi andalan daerah) konsistensinya terhadap etika bisnis metnbuat pasaran simpatik.

Dibidang sosial kemasyarakatan. Peranan orang haji menonjol pada konteks

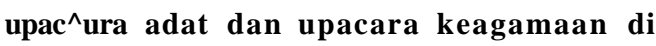
lingkungan masyarakat. Yang ditonjolkan adalah pola budaya (lokal) Sipakatau, pementasannya didominasi oleh orang haji.

Dibidang agama. Peranan orang haji pada pelataran keagamaan di masyarakat lingkungannya, tercermin dengan akhlak dan keperibadian yang terlihat bersahabat, sehingga predikat haji menjadikan penyandangnya terhisab jadi jaminan.

\section{KEPUSTAKAAN}

Aspek Geografi Budaya dalam Wilayah Pembangunan Daerah Sulawesi Selatan, 1979.

Bimbingan Ibadah Haji, Umrah dan Ziarah (D.V.A.2), Departemen Agara RI, Dirjen Bimas Islam dan Urusan Haji, Jakarta.

Doa Manasik dan Ziarah (D. V.A.4), Departemen Agama RI, Dirjen Bimas Islam dan Urusan Haji, Jakarta, 1997/1998.

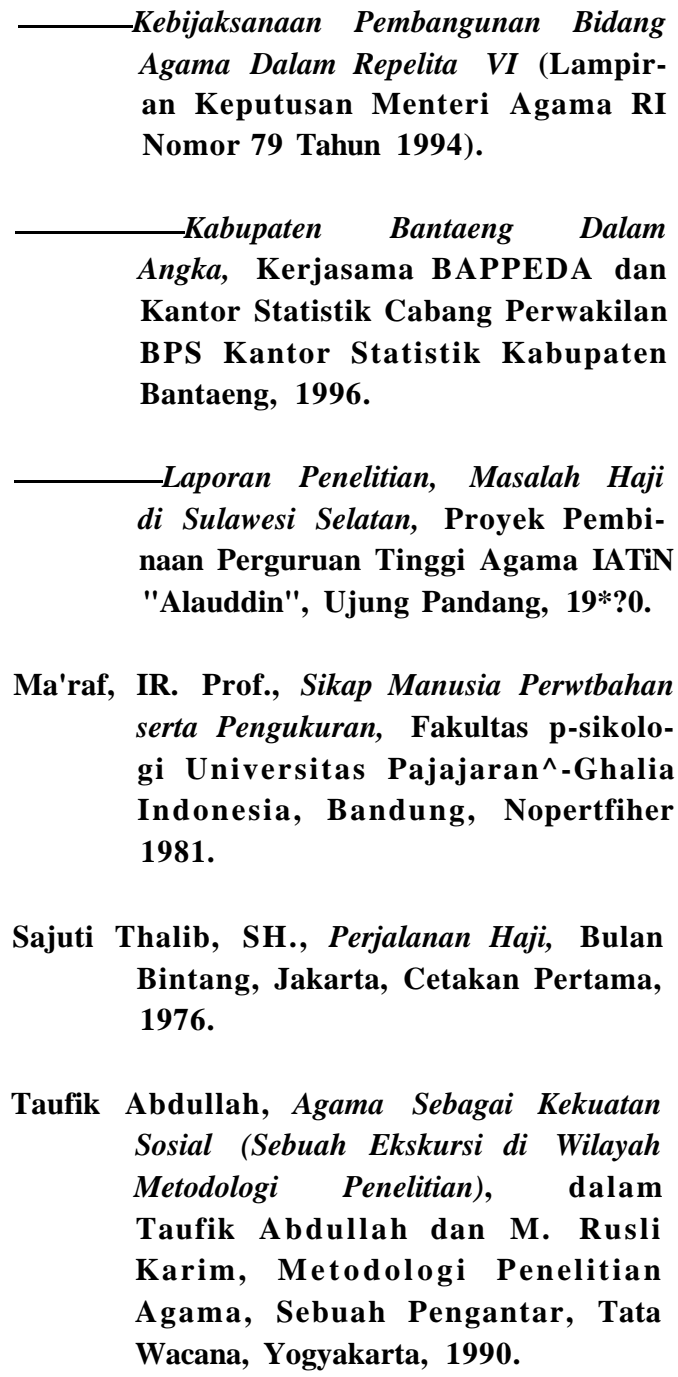

Kebijaksanaan Pembangunan Bidang gama Dalam Repelita VI (Lampiran Keputusan Menteri Agama RI omor 79 Tahun 1994).

Dalam Angka, Kerjasama BAPPEDA dan Kantor Statistik Cabang Perwakilan BPS Kantor Statistik Kabupaten Bantaeng, 1996.

LLaporan Penelitian, Masalah Haji i Sulawesi Selatan, Proyek Pembinaan Perguruan Tinggi Agama IATiN "Alauddin", Ujung Pandang, 19*?0.

IR. Prof., Sikap Manusia Perwtbahan serta Pengukuran, Fakultas p-sikologi Universitas Pajajaran^^_Ghalia Indonesia，Bandung， Nopertfiher 1981. Bintang, Jakarta, Cetakan Pertama, 1976.

Sosial (Sebuah Ekskursi di Wilayah Metodologi Penelitian), dalam Taufik Abdullah dan M. Rusli Karim, Metodologi Penelitian Wacana, Yogyakarta, 1990. 